\title{
Evaluasi Potensi Kelongsoran Pada Lereng Alam Akibat Perubahan Sudut Kemiringan Menggunakan Metode Fellenius
}

\author{
Evaluation of Natural Slopes Landslide Potentials due to Slope \\ Changing by Using Fellenius Method
}

\author{
Mila Kusuma Wardani ${ }^{1, a)}$, Felicia Tria Nuciterani ${ }^{1, b)}$ \& M. Ferdaus N. Aulady ${ }^{1, c)}$ \\ 1) Jurusan Teknik Sipil, Fakultas Teknik Sipil Dan Perencanaan, Institut Teknologi Adhi Tama, \\ Surabaya.
}

Koresponden : ${ }^{a}$ milakusuma@itats.ac.id, ${ }^{b}$ felicia@itatsac.id \& ${ }^{c}$ mohamadaulady@itats.ac.id.

\begin{abstract}
ABSTRAK
Analisa stabilitas leremg digunakan untuk prediksi nilai faktor aman yang kritis dan bidang keruntuhan potensial. Pada kondisi lereng buatan akan lebih mudah dalam melakukan prediksi tersebut, sedangkan pada kondisi lereng alam perlu diperhatikan perubahan sudut kemiringan dalam satu bentuk ketinggian. Kondisi geometri lereng alam di Kediri yang curam setinggi 15 m tanpa proteksi dapat diindentifikasi bentuk lereng menjadi 2 bagian yaitu potongan AA dan potongan BB. Berdasarkan Potongan $\mathrm{AA}$ dan potongan $\mathrm{BB}$ memiliki sudut paling kecil yaitu $51,3^{\circ}$ dan sudut kemiringan terbesar masing - masing yaitu $63.7^{\circ}$ dan $78.7^{\circ}$. Pemodelan dilakukan berdasarkan bentuk lereng alam dan memodelkan dari berbagai sudut kemiringan menggunakan program bantu Geo Slope/W dengan metode Ordinary Method Of Slices (Metode Fellenius) bidang runtuh dengan asumsi entry and exit. Dari hasil pemodelan nilai, secara umum hasil yang diperoleh, dengan meninjau setiap perubahan lereng tanpa beban, menunjukkan bahwa nilai angka keamanan yang diperoleh $\mathrm{SF}>2$ dengan bidang runtuh semakin besar. Analisa stabilitas secara keseluruhan tanpa menijau setiap perubahan sudut, nilai SF pada potongan AA adalah 1,693 dan potongan BB adalah 1.504. Kemudian apabila dimodelkan dengan menganggap lereng seragam adalah dengan kemiringan lebih dari $60^{\circ}$ nilai angka keamanan (SF) $<1$ dengan lebar kelongsoran potensial pendek.
\end{abstract}

Kata Kunci : manajemen aset infrastruktur, stabilitas lereng, fellenius, geo slope/w

\section{PENDAHULUAN}

Suatu fasilitas kompleks peternakan ayam harus dilengkapi dengan infrastruktur yang memadai. Sesuai dengan prinsip Manajemen Aset Infrastruktur, infrastruktur harus direncanakan, dirancang, diadakan, diadministrasikan dan digunakan dengan baik (Suprayitno \& Soemitro 2018). Infrastruktur pencegah kelongsoran harus direncanakan dan dirancang dengan baik.

Pembangunan kompleks peternakan ayam yang berlokasi di Kecamatan Kandangan, Kabupaten Kediri terletak pada sebuah area seluas $\pm 36 \mathrm{~m}^{2}$. Area peternakan tersebut terletak pada sebuah lereng dengan perbedaan elevasi cukup besar yaitu $\pm 14-15 \mathrm{~m}$, dan sekeliling bawah pembangunan peternakan ayam terdapat sungai sebagai sarana drainase sawah masyarakat sekitar. Namun pada proses pembangunan peternakan tidak diberi bangunan pelindung untuk lereng, sehingga dengan selesainya pembangunan peternakan terjadi kelongsoran. 
Dari terjadinya kelongsoran tersebut dapat diketahui bentuk kelongsoran yang membentuk sudut berbeda pada setiap elevasi. Analisa stabilitas umumnya dilakukan diawal sebelum pembangunan dimulai. Namun pada kondisi lereng yang mengalami keruntuhan dapat dilakukan analisa stabilitas dahulu agar pada saat melakukan perbaikan tanah sesuai. Pada kondisi lereng alam dengan bentuk sudut seragam, analisa stabilitas dapat dilakukan dengan mudah. Sedangkan pada kondisi lereng yang terletak di kompleks peternakan ayam Kediri memiliki perubahan sudut akibat kelongsoran.

Kondisi ini perlu analisa lebih dalam mengenai nilai angka keamanan dan bentuk longsor potensial kembali dari setiap perubahan lereng. Analisa stabilitas menggunakan program bantu Geo Slope/w dengan metode Fellenius bidang runtuh asumsi entry dan exit. Dari hasil analisa stabilitas yang diperoleh dapat dilakukan pertimbangan tentang metode perbaikan tanah sesuai.

\section{RUANG LINGKUP} berikut.

Ruang lingkup permasalahan pada penelitian ini telah didefinisikan dalam 3 hal sebagai

1. Analisis pemodelan kemiringan pada lereng alam.

2. Analisa stabilitas pada lereng mengikuti setiap perubahan sudut dan tidak Menggunakan Beban.

3. Analisis stabilitas menggunakan metode fellenius.

\section{TEORI DAN METODE PENELITIAN}

\section{Teori Analisis Stabilitas Lereng Metode Fellenius}

Metode ini dikenalkan pertama oleh Fellenius (1927) merupakan metode paling sederhana dalam metode irisan. Fellenius mengemukakan metodenya dengan mengasumsikan bahwa keruntuhan terjadi melalui rotasi dari suatu blok tanah pada permukaan longsor berbentuk lingkaran (sirkuler) dengan titik $\mathrm{O}$ sebagai titik pusat rotasi. Konsep ini mengganggap gaya-gaya yang bekerja pada bagian kanan - kiri irisan mempunyai resultan nol pada arah tegak lurus bidang longsornya $(\mathrm{TL}=\mathrm{TR}$ dan $\mathrm{EL}=\mathrm{ER}$ ) (Abramson et al, 2002). Gaya yang bekerja pada bidang pada setiap potongan diberikan pada Gambar 1 . Fellenius menghasilkan nilai SF yang lebih rendah dari cara hitungan yang lebih teliti.

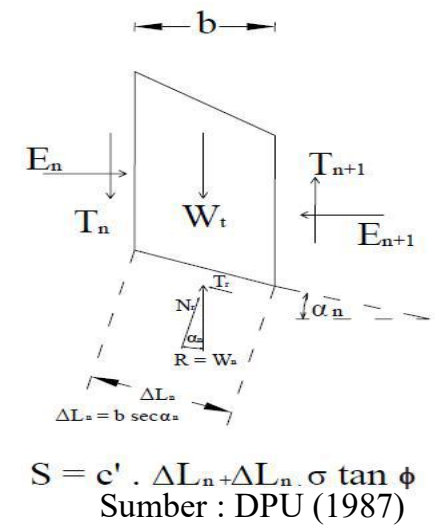

Gambar 1. Gaya yang bekerja pada metode Fellenius

Menurut Hardyatmo (2012) metode ini banyak digunakan dalam praktek, karena cara hitungan menurut Fellenius sederhana dan kesalahan yang terjadi pada sisi aman. Batasan nilai-nilai kesalahan mencapai kira-kira $5-40 \%$ tergantung dari nilai faktor aman, sudut pusat lingkaran yang dipilih dan besarnya tekanan air pori. Untuk menentukan faktor aman 
yang kritis, terlebih dahulu ditentukan letak pusat lingkaran dan jari-jarinya guna membuat bidang keruntuhan. Dengan demikian, diperlukan beberapa percobaan bidang keruntuhan untuk menghasilkan nilai safety factor yang paling minimum (Muntohar, 2015).

\section{METODE PENELITIAN} berikut.

Secara umum Metoda Penelitian yang dilakukan mengikuti tiga tahap analisis sebagai

1. Tahap persiapan

Pengumpulan data geometri lereng serta potongan lereng. Dimana dari data geoemtri dapat dilihat letak lokasi kelongsoran terjadi dan pada potongan dapat diketahui bahwa bentuk serta elevasi lereng berbeda. Selain itu dari bentuk potongan lereng ditentukan titik pengambilan contoh tanah untuk dilakukan uji laboratorium.

2. Tahap analisa stabilitas

Data tanah hasil pengujian laboratorium kemudian digunakan sebagai input pemodelan pada Geo Studio. Slope/W. Analisa stabilitas pada setiap potongan lereng dilakukan dengan beberapa tahapan yaitu :

3. Analisa dengan mempertimbangkan kondisi keseluruhan bentuk lereng. Analisa dengan perubahan setiap sudut pada satu kondisi lereng.

Dari hasil analisa yang sudah diperoleh, yang diamati adalah nilai SF serta bentuk kelongsoran yang terjadi dan potensi kelongsoran pada analisa stabilitas.

\section{PEMBAHASAN}

\section{Data Geometri Lereng}

Lokasi kelongosoran diberikan pada Gambar 1 dimana pada gambar yang diarsir merupakan daerah yang paling parah. Bentuk kelongsoran diberikan pada dua potongan melintang yaitu pada Gambar 2 dan Gambar 3. Sesuai gambar potongan melintang dilakukan pengambilan sampel tanah pada perubahan kemiringan sudut.

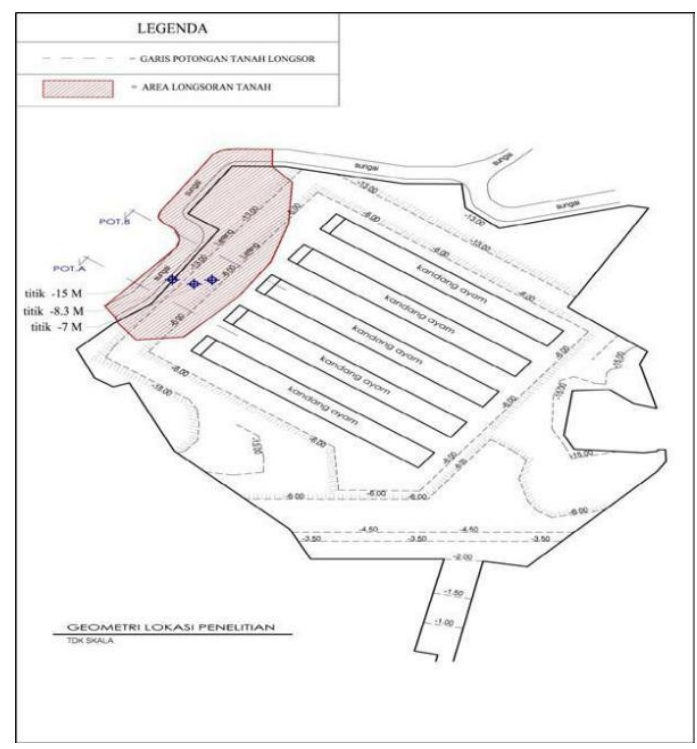

Gambar 1. Lokasi Kelongsoran 


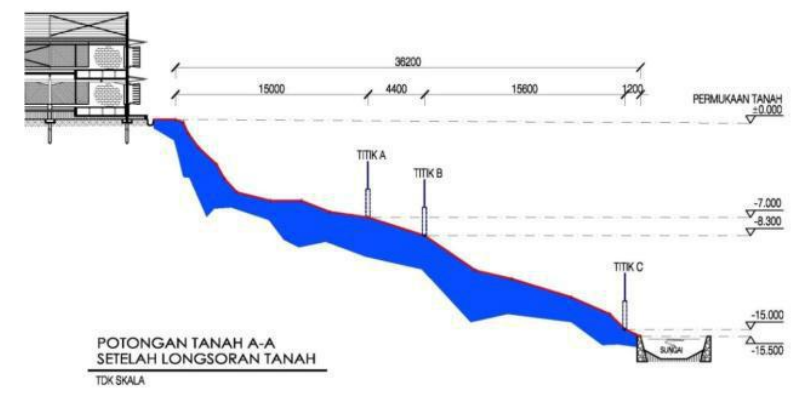

Gambar 2. Potongan AA Kelongsoran

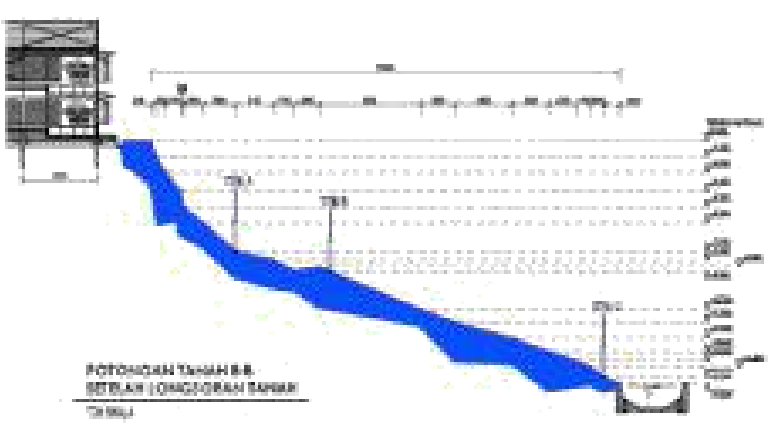

Gambar 3. Potongan BB Kelongsoran

Dari Gambar 2 dan Gambar 3 dapat diidentifikasi beberapa perubahan sudut kemiringan pada setiap potongan AA dan potongan BB pada Tabel 1.

Tabel 1. Sudut dari setiap potongan

\begin{tabular}{ccc}
\hline No. & \multicolumn{2}{c}{ Sudut Kemiringan Terbesar ( ) } \\
\hline & Potongan AA & Potongan BB \\
\hline 1. & 51.3 & 51.3 \\
2. & 59 & 68.2 \\
3. & 63.4 & 78.7 \\
\hline \multicolumn{2}{l}{ Sumber : Hasil Pengolahan Data (2018) }
\end{tabular}

\section{Data Geometri Lereng}

Pengujian dilakukan dalam skala laboratorium yaitu dengan pengujian Direct Shear Test (DST) dan Pengujian Volumetri Gravimetri. Dari dua pengujian dapat diperoleh nilai kohesi (c), sudut gesek dalam $(\varphi)$ dan berat volume $(\gamma)$ yang dimasukkan dalam pemodelan dengan menggunakan program Geo Studio Slope/W. Hasil penyelidikan tanah diberikan pada Tabel 2.

Tabel 2. Data Tanah Berdasarkan Hasil Pengujian Laboratorium

\begin{tabular}{cccccc}
\hline \multirow{2}{*}{ Kedalaman (h) } & Kohesi (c) & Sudut Geser Dalam & Berat Volume & Berat Jenis & Kadar Air \\
& & Dalam & Volume & Jenis & Air \\
$\mathrm{m}$ & $\mathrm{kN} / \mathrm{m}^{2}$ & 0 & $\mathrm{kN} / \mathrm{m}^{3}$ & & $\%$ \\
\hline 7 & 27.5 & 22 & 15.559 & 2.261 & 50.98 \\
8.3 & 14.5 & 32 & 15.029 & 2.466 & 58.79 \\
\hline
\end{tabular}

Sumber : Hasil Pengolahan Data (2018) 


\section{Analisa Stabilitas}

Analisis yang dilakukan dengan program bantu Geo Studio Slope/ W 2012 dengan membagi pias menjadi 5, 10, 15, 20, 30 dan 50 irisan berdasarkan asumsi Ordinary Method Of Slices (Metode Fellenius). Pemodelan lereng pada Geo Studio Slope/ W 2012 sesuai dengan Gambar 2 dan Gambar 3, lereng didefinisikan berdasarkan teori Mohr-Coloumb dengan input data berupa Tabel 1.

Hasil analisa stabilitas yang diperoleh pada Potongan Kelongsoran AA disampaikan pada Gambar 4 dan Gambar 5 sebagai berikut.

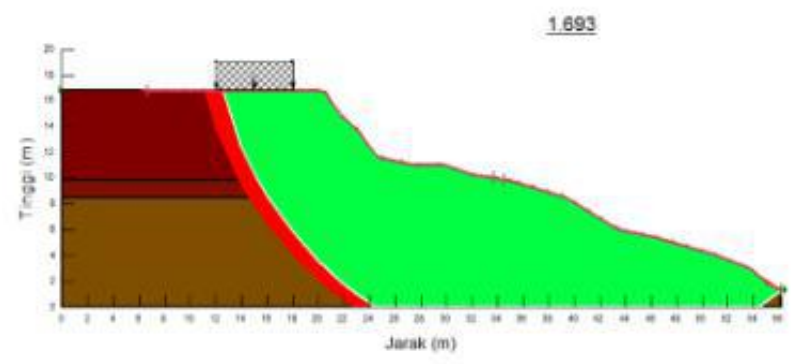

Gambar 4. Analisa Stabilitas Keseluruhan pada Potongan AA
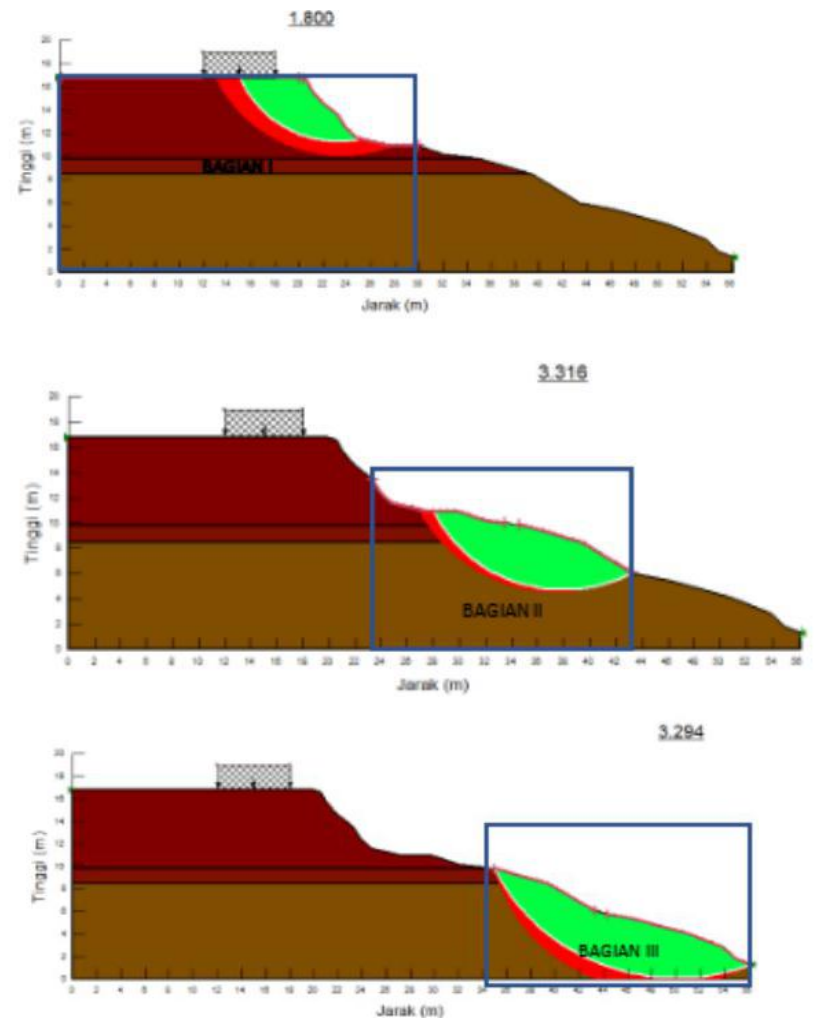

Gambar 5. Stabilitas Pada Setiap Perubahan pada Potongan AA 
Hasil analisa stabilitas yang diperoleh pada Potongan Kelongsoran BB disampaikan pada Gambar 6 dan Gambar 7 sebagai berikut.

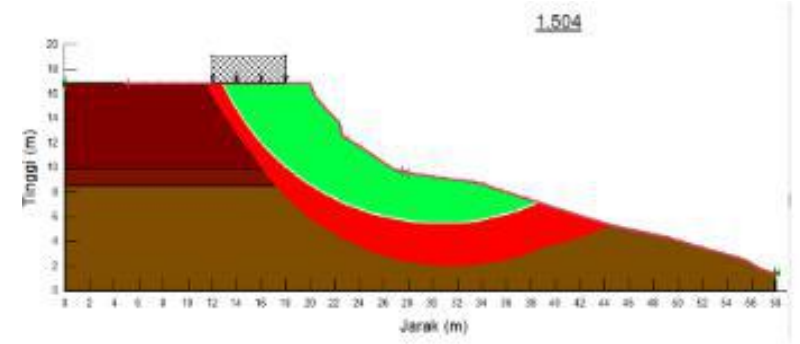

Gambar 6. Analisa Stabilitas secara Keseluruhan pada Potongan BB
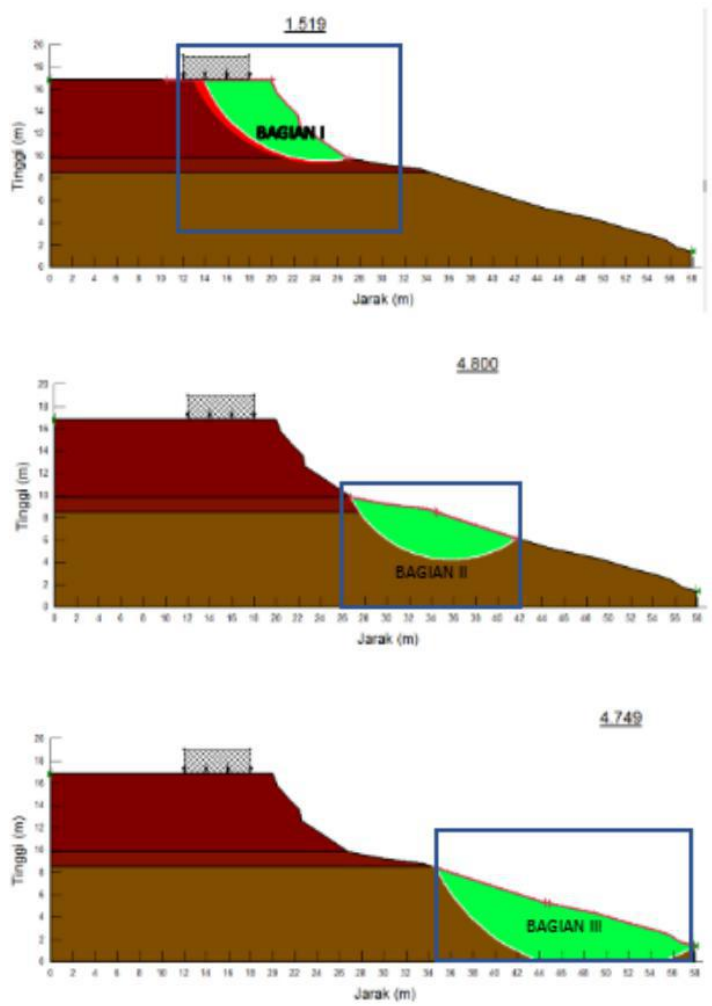

Gambar 7. Analisa Stabilitas pada Setiap Perubahan Sudut pada Potongan BB

Pada potongan BB menunjukkan bahwa secara keseluruhan nilai angka keamanan lebih kecil yaitu 1.504. Sedangkan pada analisa stabilitas dengan mempertimbangkan perubahan sudut memiliki kecenderungan sama yaitu nilai angka kemanan besar. Namun pada bagian II dan bagian III potensi kelongsoran yang terjadi kecil.

Dari hasil analisa setiap bentuk dan secara keseluruhan pada potongan AA dan potongan $\mathrm{BB}$, langkah selanjutnya melakukan analisa dengan berbagai sudut pada potongan dengan elevasi $15 \mathrm{~m}$. Hasil analisa stabilitas dapat diperoleh pada Tabel 3 yaitu pada kondisi tanpa pembebanan dan Tabel 4 dengan pembebanan. 
Tabel 3. Rekapitulasi Analisa stabilitas tanpa pembebanan

\begin{tabular}{cccccc}
\hline \multicolumn{7}{c}{ Sudut Kemiringan Lereng (o) } \\
\hline $\mathrm{SF}$ & 1,221 & 1,124 & 1,072 & 1,019 & 0.889 \\
\hline $\mathrm{Mr}$ & & $\mathbf{5 9}$ & $\mathbf{6 3 . 4}$ & $\mathbf{6 8 . 2}$ & $\mathbf{7 8 . 7}$ \\
\hline$(\mathrm{kN}-$ & $14.484,326$ & $12.296,409$ & $15.715,891$ & $15,169.60$ & $22,077.28$ \\
$\mathrm{~m})$ & & & & & \\
\hline $\mathrm{Md}$ & & & & & \\
$(\mathrm{kN}-$ & $11.867,397$ & $10.941,422$ & $14.667,127$ & $14,881.22$ & $24,827.64$ \\
$\mathrm{~m})$ & & & & & \\
\hline
\end{tabular}

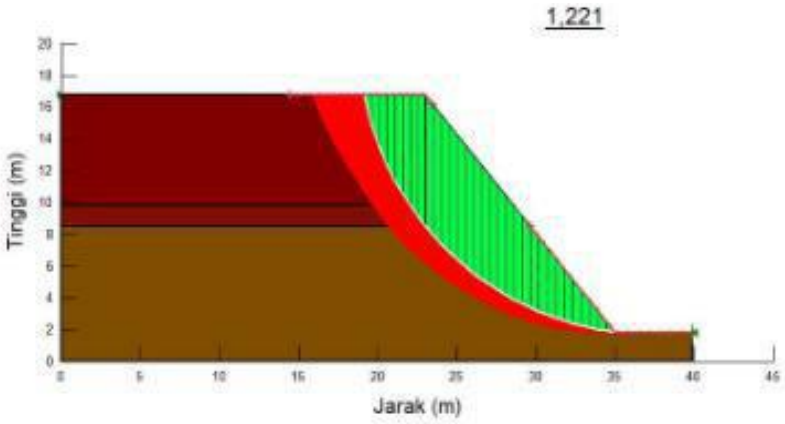

SF 51.3

Gambar 8. Analisa Stabilitas dengan Pemodelan 51.3

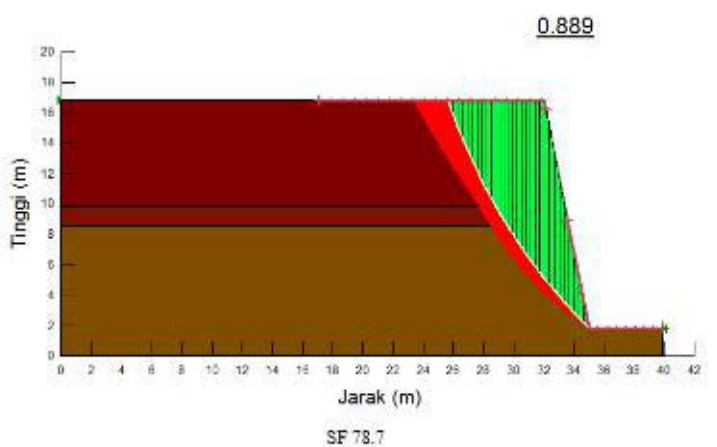

Gambar 9. Analisa Stabilitas dengan Pemodelan $78.7^{\circ}$

Analisa selanjutnya adalah dengan menggunakan beban merata $\mathrm{q}=25,91 \mathrm{kN} / \mathrm{m}^{2}$ dengan perhitungan berat terdekat gedung dan dibagi luasan pondasi yang mendekati area permukaan lereng. 
Tabel 3. Rekapitulasi Analisa stabilitas tanpa pembebanan

\begin{tabular}{cccccc}
\hline \multicolumn{5}{c}{ Sudut Kemiringan Lereng (o) } \\
\hline SF & $\mathbf{5 1 . 3}$ & $\mathbf{5 9}$ & $\mathbf{6 3 . 4}$ & $\mathbf{6 8 . 2}$ & $\mathbf{7 8 . 7}$ \\
\hline Mr & 1,032 & 0,938 & 0,888 & 0,837 & 0.723 \\
$(\mathrm{k}$ & $21,124.00$ & $19,204.70$ & $24,175.70$ & $22,514.00$ & $40,320.80$ \\
$\mathrm{~N}-$ & 43 & 16 & 21 & 26 & 92 \\
$\mathrm{~m})$ & & & & \\
$\mathrm{Md}$ & & & & \\
$(\mathrm{k}$ & $20,473.70$ & $20,479.90$ & $27,224.40$ & $22,514.00$ & $55,762.30$ \\
$\mathrm{~N}-$ & 24 & 2 & 23 & 26 & 55 \\
$\mathrm{~m})$ & & & & & \\
\hline
\end{tabular}

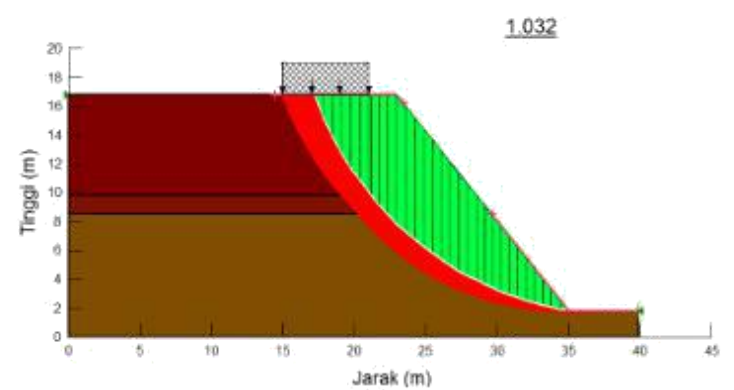

Gambar 10. Analisa Stabilitas dengan Pembebanan Pemodelan $51.3^{\circ}$

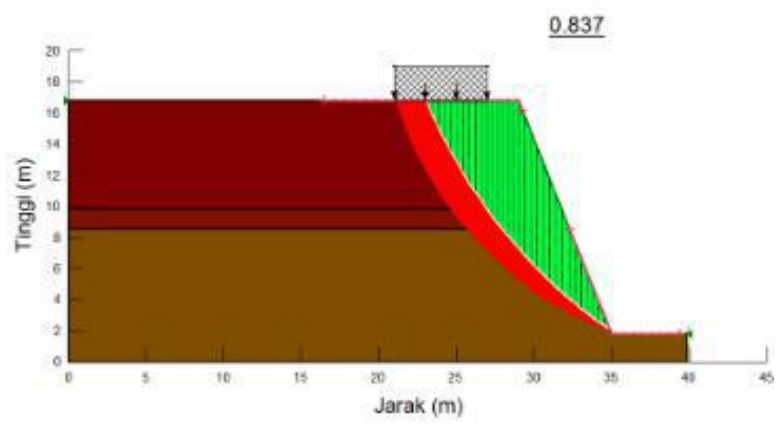

Gambar 11. Analisa Stabilitas dengan Pembebanan Pemodelan $78.7^{\circ}$

\section{KESIMPULAN}

Dari hasil analisa dan perhitungan dapat diperoleh beberapa kesimpulan pokok sebagai berikut :

1. Pada potongan lereng AA dan potongan BB memiliki sudut sama yaitu $51.3^{\circ}$ dengan sudut terbesar masing - masing adalah $63.4^{\circ}$ dan $78.7^{\circ}$.

2. Dari analisa stabilitas secara keseluruhan dapat diperoleh bahwa kondisi potongan AA memiliki nilai SF 1,693 dan SF 1,504

3. Analisa stabilitas pada setiap bagian perubahan sudut diketahui bahwa nilai angka Keamanan $n>2$. Potensi kelongsoran yang terjadi lebih besar pada bagian kaki lereng, dimana kaki lereng adalah sudut kemiringan besar.

4. Potensi kemungkinan longsor pada potongan AA pada ujung kaki lereng lebih besar dibandingkan dengan potongan $\mathrm{BB}$.

5. Apabila dilakukan pemodelan dengan ketinggian lereng $15 \mathrm{~m}$ diperoleh bahwa dengan dan tanpa pembebanan nilai angka keamanan $<1.5$ dan memiliki potensial kelongsoran pada sudut terkecil dan sudut terbesar. 


\section{SARAN}

Setelah melakukan analisis, beberapa saran penting telah terpikirkan dan disampaikan sebagai berikut :

1. Analisa stabilitas dapat ditambah dengan metode irisan lainnya seperti metode Bishop.

2. Perlu analisa metode perbaikan tanah dengan menyesuaikan dari perubahan sudut kemiringan lereng.

\section{DAFTAR PUSTAKA}

Abramson, L.W., Lee, T.S., Sharma, S. \& Boyce, G.M. (2002). Slope Stability and Stabilization Method. Second Edition. John Wiley \& Sons, Inc. New York.

BNPB (2013). Indeks Rawan Bencana Indonesia : Bencana Tanah Longsor. Badan Nasional Penanggulangan Bencana. Jakarta.

SNI 13-7124-2005. (SNI 13-7124-2005 : Penyusunan Peta Zona Kerentanan Gerakan Tanah). BSN. Jakarta.

Das, B. M. (1995). Mekanika Tanah (Prinsip-prinsip Rekayasa Geoteknis). Jilid 2. Erlangga. Jakarta.

DPU (1987). Petunjuk Perencanaan Penanggulangan Longsoran, SKBI - 2.3.06. Yayasan Badan Penerbit PU. Departemen Pekerjaan Umum. Jakarta.

Hardyatmo (2012). "Tanah Longsor Dan Erosi" . Gadjah Mada University Press. Yogyakarta.

Muntohar, Agus Setyo (2006). "Pengaruh rembesan dan kemiringan lereng terhadap keruntuhan lereng". Jurnal Teknik Sipil Universitas Cokroaminoto Yogyakarta Volume 1, Nomor 2, Agustus 2006.

Nur Arifin (2015). Analisis Faktor Keamanan (Safety Factor) Stabilitas Lereng Menggunakan Geo-Slope $W$ 2012. Program Studi Teknik Sipil. Fakultas Teknik Universitas Majalengka. Majalengka.

Suprayitno, H. \& Soemitro, R.A.A. (2018).'Preliminary Reflexion on Basic Principle of Infrastructure Asset Management”. Jurnal Manajemen Aset Infrastruktur \& Fasilitas, Vol.2, No.1, Maret 2018, Hal : 1-9.

Wardani, K., Nuciferani, F.T. \& Aulady, M.F.N. (2018). "Perencanaan dinding penahan tanah untuk menanggulangi kelongsoran pada kompleks peternakan ayam di Kecamatan Kandangan, Kediri, Jawa Timur". Jurnal Teknik Sipil Borneo Engineering, Volume 2, Nomor 2, Desember 2018. 
(e)ISSN 2615-1847 (p)ISSN 2615-1839

Jurnal Manajemen Aset Infrastruktur \& Fasilitas - Vol. 3, Edisi Khusus 2, Juni 2019 